\title{
術前に前縦隔腫瘍と診断された限局性 線維性胸膜中皮腫の一例
}
富山 憲一，福瀬 達郎，中村 隆之，池修，乾健二 水野 浩，横見瀬裕保，和田 洋巳，人見 滋樹

\section{要旨}

症例は56歳，女性. 咳嗽，体重減少を主訴に近医を受診し，胸部異常陰影を指摘された。CTを中心 とした画像診断を行い，前縦隔腫瘍と診断し，手術目的で当院に入院した. 腫瘍摘出術を施行したとこ ろ, 腫瘍は左 $\mathrm{S}^{3} \mathrm{~b}$ 領域の臓側胸膜に有茥性に付着していた. 病理䛦断の結果, 腫瘍は紡鍾形細胞と線維 組織からなり，限局性線維性胸膜中皮腫であることが判明した．術前に腫瘍の位置が縦隔か胸腔内か を，画像上で区別するのは困難であったが，術後の再検討の結果，MRI では縦隔脂肪織がよく描出さ れ，CT に比べ鑑別に有効だと考兄られた．有茎性の胸膜中皮腫は肺内腫瘍との鑑別が困難であること が多いが，今回の症例のように縦隔腫瘍との鑑別が困難な例は稀であり，報告した.

索引用語：限局性胸膜中皮腫, 前縦隔腫瘍 localized pleural mesothelioma, anterior mediastinal tumor

\section{はじめに}

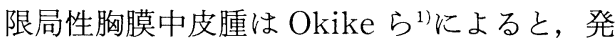
生頻度は 10 万人に対し 2.8 人であり, 稀な疾患で ある．肺腫瘍や，胸壁腫痬との鑑別が問題とな ることが多いが，縦隔に接して発育する場合縦 隔腫瘍との鑑別の難しさが指摘されている21. われわれは術前，画像所見から前縦隔腫瘍と診 断し手術を行った限局性線維性胸膜中皮腫の 1 例を経験したので，文献的考察を加えて報告す る.

\section{症例}

症 例：56歳，女性.

主 訴：胸部異常陰影，咳嗽，体重減少，易 疲労感.

京都大学胸部疾患研究所 呼吸器外科

原稿受付 1995年11月 8 日

原稿採択 1996年 2 月21日
家族歴：特記すべきことなし．

既往歴：46歳のとき子宮筋腫, 卵巣腫瘍のた め, 子宮卵巣全摘術.

䝟煙習慣なし，抗生剤(サルファ剂)，造影剂 などによるアレルギーの既往あり。

現病歴：1991年ごろから，咳嗽の出現が見ら れた. 1992年 2 月に某病院にて撮影した胸部X 線上で異常陰影が認められたが，精査は行われ なかった。1994年秋より，咳嗽の増強，易疲労 感, 体重減少 ( $-5 \mathrm{~kg} / 5$ 力月)があり，1995年 1 月に近医による胸部X線上で異常陰影を指摘 され，単純及び造影胸腹部 CT, 胸部 MRI の 所見から前縱隔腫瘍が疑われた。治療目的で当 科を紹介され，5月25日に入院した。

入院時所見：頝，胸，腹部，四肢関節などの 理学的所見に異常を認めず，血液一般，生化学， 尿, 肺機能検査, 血液ガス, 腫瘍マーカーなど は総て正常範囲内であった。

入院時胸部 X線所見 (1995年 5 月)：左肺門部 に5.6×2.0 cm の異常陰影が認められた（Fig. 


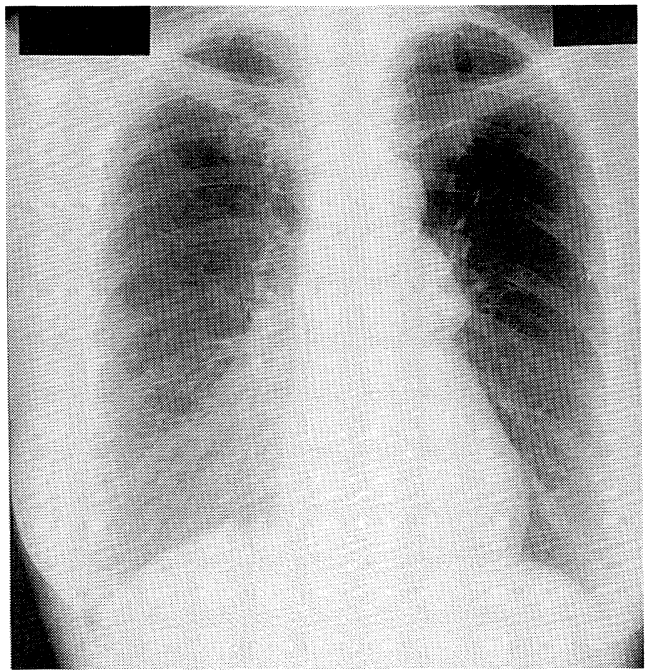

Fig. 1 Chest roentgenogram on admission showing an abnormal shadow in the left hilum.

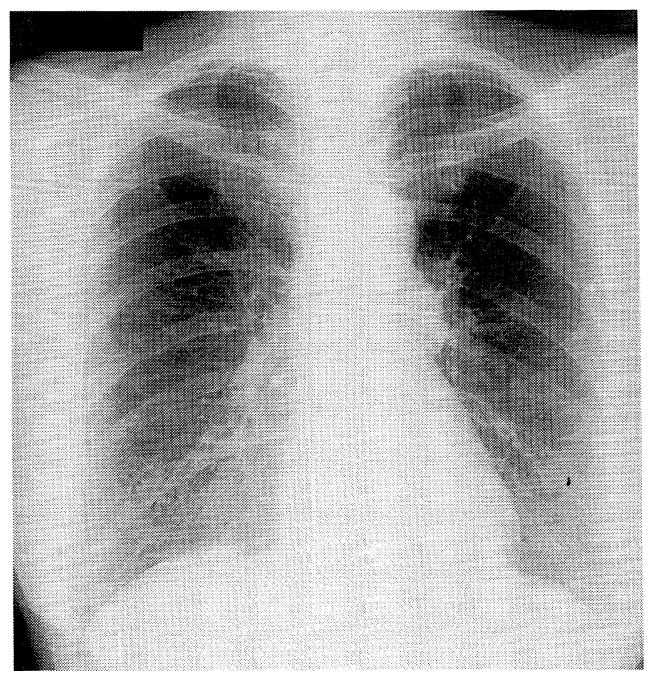

Fig. 2 Chest roentgenogram of February 1992 showing the same abnormal shabow in the left hilum.

1）。た，1985年 4 月の子宮卵巣全摘術前の胸 部 X線では異常は認められなかったものの, 1992年 2 月の撮影でも左肺門部に $5.0 \times 1.5 \mathrm{~cm}$ の異常陰影（Fig. 2）を認めた.

胸部単純 CT 所見：主肺動脈前方に充実性の $5.1 \times 4.0 \times 2.7 \mathrm{~cm}$ の腫瘤陰影を認めた（Fig. 3). 腫瘤影は上行大動脈, 左肺動脈, 肺動脈本

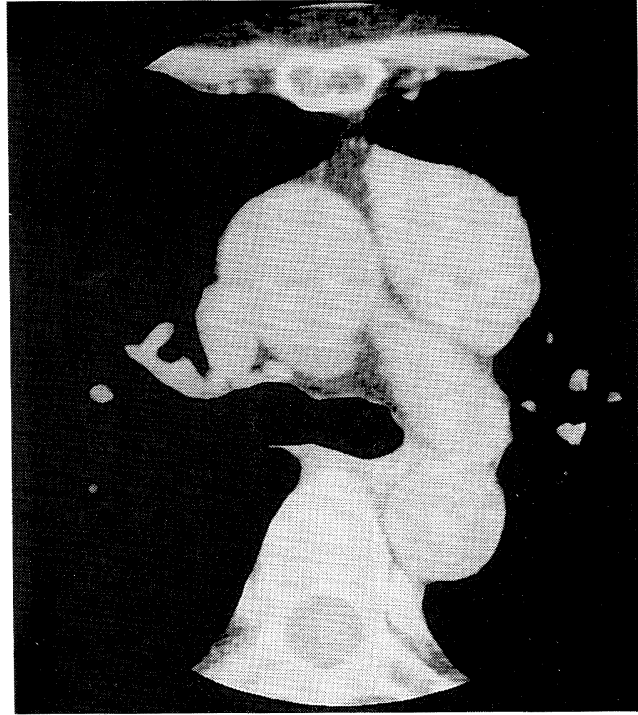

Fig. 3 CT scan showing $5.1 \times 4.0 \mathrm{~cm}$ mass anterior to main pulmonary artery.

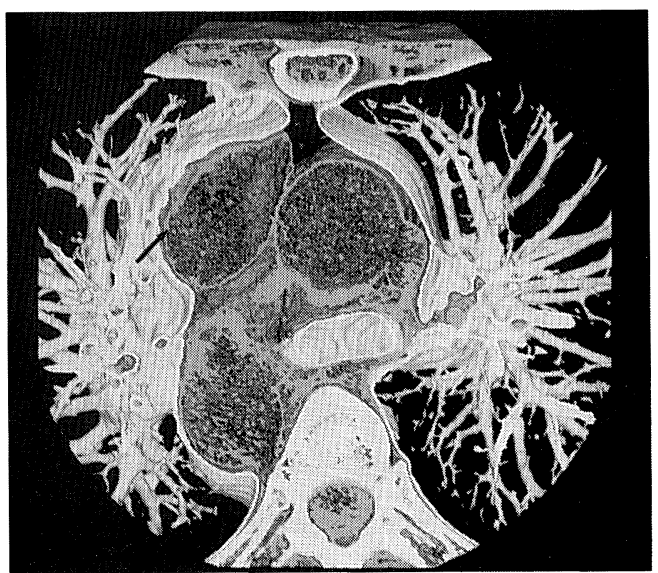

Fig. 4 3D CT scan showing the tumor (allow) apparently located in the anterior mediastinum.

幹部〜心膜と接するものの，圧排，浸潤は認め られず，また肺との境界は平滑だった．胸水， リンパ節腫大は見られなかった。

3 次元 CT 所見：上行大動脈の左方に接する 腫瘤影が見られ, 縦隔内の腫瘤と判断した(Fig. 4).

MRI 所見：T1 強調画像で腫瘍影と上行大 動脈执よび左肺動脈との間に high density 


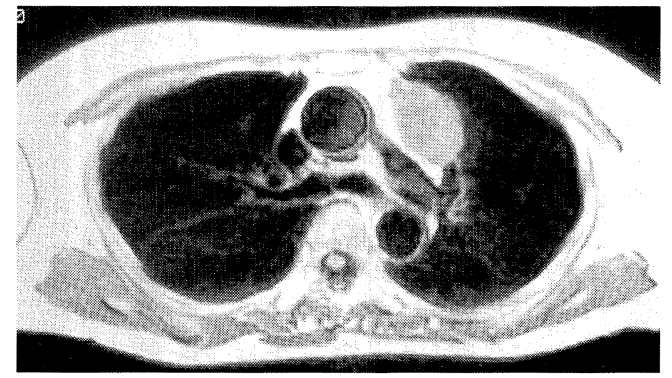

Fig. 5 MRI showing a high density area between the tumor and the left pulmonary artery.

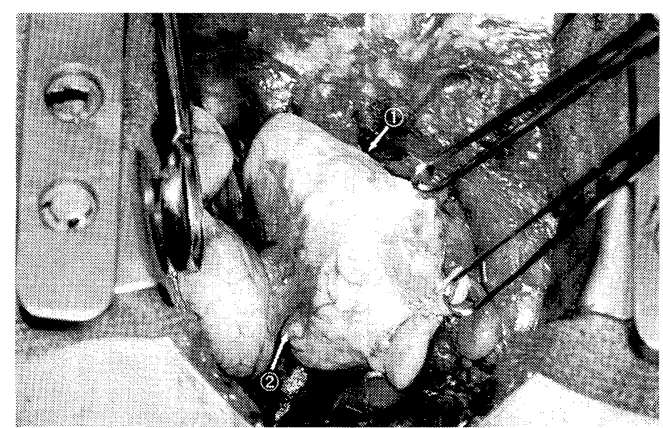

Fig. 6 A tumor (allow (1)) attached to left $\mathrm{S}^{3}$ visceral pleura with a stalk (allow (2)) $1 \mathrm{~cm}$ in diameter.

area が存在し, 腫瘍組織は肺実質と密接して存 在していた（Fig. 5). 前縦隔腫瘍と診断し，と りわけ胸腺腫を疑い，抗アセチルコリンセレプ タ一抗体検査や，筋電図なども行ったが，異常 は認められなかった. 1995年 6 月 8 日，腫瘍摘 出術が施行された。

手術所見：腫瘍は $7.0 \times 5.0 \times 2.5 \mathrm{~cm}$ ，灰白色 で弾性硬，表面平滑であった，左の縦隔胸膜下 の胸腔内に存在しており, 左 $S^{3} b$ 領域の蔵側胸 膜に直径約 $1 \mathrm{~cm}$ の茎により有茎性に付着して いた (Fig. 6). 茎付着部周囲の肺実質に直径 2 $\sim 3 \mathrm{~cm}$ の範囲で軽度の発赤を認めたため, 同 部位の藏側胸膜および肺組織とその周囲を切離 し，病变部とともに摘出した。

病理所見：組織学的に, 腫痬は細胞成分の少 ない濃密な線維状組織からなる部分 (Fig. 7a) と, 紡維形細胞が束をなして, 流線状に増成し ている部分（Fig. 7b）とからなっていた. 後者

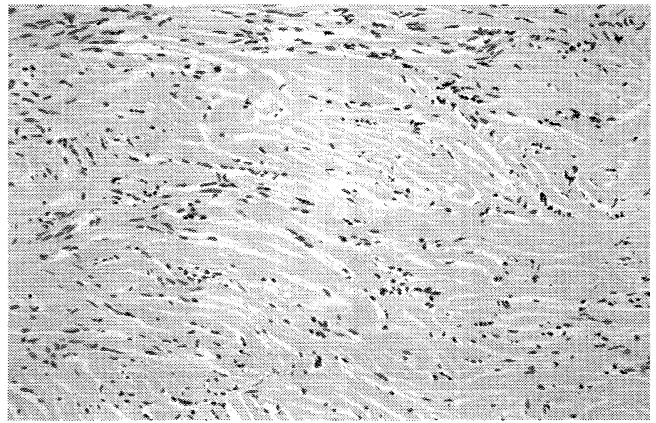

(a) The tumor is rich in fibrous tissue. (HE stain, $\times 100$ )

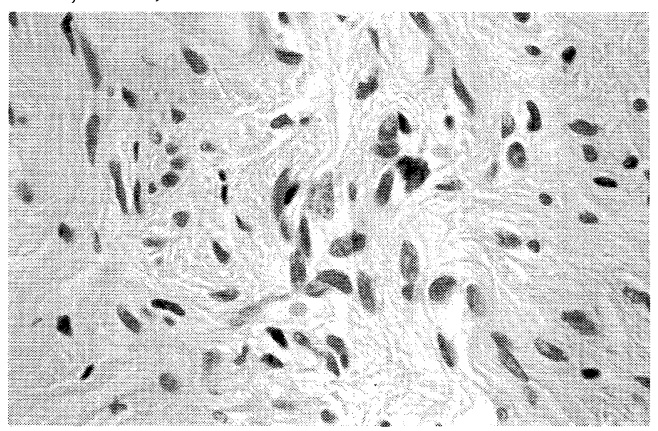

(b) The tumor contains many spindle cells. (HE stain, $\times 400$ )

Fig. 7 Microscopic appearance of resected specimen

の組成が大半であり, 紡維形細胞の核異型, mitosis は軽度であった．また，上皮細胞成分は 認められなかった. van Gieson 弾性染色, Azan 染色, 鍍銀染色では, 線維性成分の増成が著明 に見られた. Alcian blue 染色は陽性であった が，ヒアルロニダーゼにより染色性が低下した。 PAS 染色は陰性であり, Vimentin 染色は陽性 であった。

以上の所見より，限局性線維性胸膜中皮腫と 診断した.

術後経過：術後経過良好で術後22日目に退院 した。な拈，術前に見られた咳嗽の著明な減少 が見られた。

\section{考察}

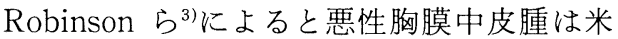
国で年間2000～3000例発見されており，全癌の 
約 $0.2 \%$ の発生頻度である. 限局性胸膜中皮腫は 大半は良性であり，胸膜中皮腫全体の $10 \%$ 占 めるとされている. 本邦症例は1991年に八田 ら ${ }^{4)}$ が限局性胸膜中皮腫の123例を集計して報 告し, 組織学的には線維性, 上皮性, 混合性に 分類されるが，大部分が線維性であったと述べ ている. 発生部位については, 臓側胸膜発生が $70 \%$, 壁側胸膜発生が30\%とされるが5)，この点 に関し, Briselli ら ${ }^{6)}$ は臓側胸膜発生が壁側胸膜 発生の約 4 倍あると報告している．末た，形態 面から有茎性，広基性に分けることができるが， 有茎性が $2 / 3$ ，広基性が $1 / 3$ と有茎性のものが多 ${ }^{5}$, 悪性のものは広基性である場合が多い. 術 前に施行された 2 次元の CT では胸膜は描出 されて扣らず，造影の有無にかかわらず，病変 が胸腔内にあることを指摘するのは不可能であ った．また， 3 次元 CT に招いても腫瘍を覆う 縱隔胸膜は明確ではなく, 腫瘍は胸腔外に存在 しているよらに思われた，MRI では，T1 強調 画像で腫瘍組織と上行大動脈および左肺動脈と の間に high density area が存在していた. retrospective に MRI の所見を検討すると, 縦 隔脂肪織が描出されていることから，この所見 は腫瘍が縦隔外に存在することを示唆している ものと考兄られ, 本症例の画像診断上, MRI は CTより有用であったとも言える. 本腫瘍は有 茎性に発育したが，CT 预よび MRI に招いて， 茎の存在を指摘しらる所見は得られなかった。 Mendelson らも本疾患の CT 所見で茎の存在 が確認されたものは20例中 4 例に過ぎなかった としている7.なお，経皮的針生検は確診率の低 さ8), 及び穿刺部位からの腫瘍の再発の危険性 ${ }^{9}$ から, 本疾患の診断上確立された手法とは言兄 ない.

臨床症状が少なく, 一般検査成績に異常を認 めないことが限局性線維性胸膜中皮腫を疑う根 拠になるともされるが10), Briselli らは64\%に 症状が見られたとしており，咳嗽，胸背部痛， 呼吸困難, 骨関節症, 発熱の出現などをあげて いる。本症例においても, 術前に著明な咳嗽が みられ，術後に消失をみた。咳嗽は約 4 年前か ら出現して抢り，この頃にすでに腫瘍の発生が
あったとも考えられる. 3 年前の胸部X線に招 いて, 腫瘍の存在は明らかで, 確診のための精 査が行われていなかったために，3 年以上にわ たる緩慢な腫瘍の発育を証明する結果となった。 なお，限局性胸膜中皮腫は一般に緩慢な発育を するとされ，約 5 年にわたり発育した巨大腫瘍 の報告例もある ${ }^{11)}$.

本腫瘍は肉眼的に薄い被膜で覆われ, 被膜外 浸潤は見られなかった。 また組織学的に上皮性 成分に乏しく，膠原線維化が高度であることは 良性の指標とされる ${ }^{6}$. 以上の肉眼的, 組織学的 所見及び緩徐な発育速度から, 本症例は良性と 判断されるが, 伴場ら ${ }^{9}$ とよると, 限局性胸膜腫 瘍の切除後再発34例中14例は初回手術時に良性 と診断された症例であったという。本症例に沶 いても, 術後長期にわたる厳重な経過観察が必 要不可欠であるといえるだろう.

\section{結語}

1 ）画像所見から前縦隔腫瘍が疑われた症例に 対して, 腫瘍摘出術を実施した. 腫瘍は限局性 線維性胸膜中皮腫であり, 左 $\mathrm{S}^{3} \mathrm{~b}$ 領域の藏側胸 膜に有茎性に付着していた。

2 ）本症例のように，縦隔に接して発生した限 局性胸膜中皮腫の画像による術前診断は困難で あるが，MRI が有効な場合もある.

\section{文献}

1) Okike N, Bernatz PE, Woolner LB : Localized mesothelioma of the pleura. Benign and malignant variants. J Thorac Cardiovasc Surg $75: 363-372,1978$.

2）岩永知秋, 本広 昭, 栗田幸男, 他：画像上縦 隔腫瘍との鑑別が困難であった，79歳女性，左 上葉肺胸膜発生の良性限局型胸膜中皮腫の 1 手術例. 日胸臨床 52 (9)：772-776, 1993.

3) Robinson LA, Reilly RB : Localized pleural mesothelioma. The clinical spectrum. Chest $106: 1611-1615,1994$.

4）八田 建, 大薮久則, 栗栖 茂, 他：限局性線 維性胸膜中皮腫の 1 手術例: 胸部外科 44 (4):344-346, 1991.

5）田野正夫：限局型胸膜中皮腫，良性胸膜中皮 腫. 別冊 日本臨牀 領域別症候群 $3: 811-$ 814, 1994.

6) Briselli $M$, et al: Solitary fibrous tumors of the pleura. Cancer $47: 2678-2689,1981$.

7) Mendelson DS, Meary E, Buy JN, et al: 
Localized fibrous pleural mesothelioma : CT findings Clin Imag 15 : 105-110, 1991.

8）松井 寛, 安藤重満, 佐竹 章, 他：MRI が診 断に有効であった限局性線維性胸膜中皮腫の 1 例. 日胸臨床 51（9）：787-791，1992.

9）伴場次郎, 友安 浩, 谷村繁雄, 他：限局型胸 膜中皮腫 6 手術例の検討. 日胸会誌 $31(10)$ : 110-115, 1893.
10) Maltry DE, Schenken JR, Neis DD : Fibrous mesothelioma. Nebr Med J 65: 126-130, 1980.

11）星永 進, 青山克彦, 高柳 昇：日呼外会誌 7 (7) : 845-849, 1993.

\title{
Localized pleural mesothelioma preoperatively diagnosed as anterior mediastinal tumor; report of a case
}

\author{
Kenichi Tomiyama, Tatsuro Fukuse, Takayuki Nakamura \\ Hiroyasu Yokomise, Hiroshi Mizuno \\ Kenji Inui, Osamu Ike, Hiromi Wada, Shigeki Hitomi \\ Department of Thoracic Surgery, Chest Disease Research Institute, Kyoto University, \\ Shogoin Kawahara-cho 53, Sakyo-ku Kyoto 606
}

A 56-year-old woman was admitted to our hospital showing an abnormal left pulmonary hilar shadow on a chest X-ray film.

Furthre examinations, including a 3D CT scan, led to a diagnosis of anterior mediastinal tumor. The tumor was removed and found to be a localized pleural mesothelioma attached to the visceral pleura with a stalk. It was difficult to preoperatively diagnose whether the tumor was located in the mediastinum or the pleural space. Retrospective opinion was that MRI was more useful than CT scan in defining this tumor. 